Research Paper

\title{
Sesamin modulates tyrosine hydroxylase, superoxide dismutase, catalase, inducible N0 synthase and interleukin-6 expression in dopaminergic cells under $\mathrm{MPP}^{+}$-induced oxidative stress
}

\author{
Vicky Lahaie-Collins, ${ }^{1}$ Julie Bournival, ${ }^{1}$ Marilyn Plouffe, ${ }^{1}$ Julie Carange ${ }^{1}$ and Maria-Grazia Martinoli 1,2

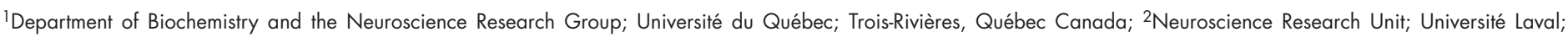 \\ Québec Canada
}

\begin{abstract}
Abbreviations: CAT, catalase; Ct, mean cycle threshold values; DA, dopamine; DAergic, dopaminergic; DAPI, 4',6-diamidino-2-phenylindole; DAT, dopamine transporter; DHR, dihydrorhodamine 123; DMEM-F12, Dulbecco's modified Eagle's medium-F12 ham; DMSO, dimethylsulfoxide; ER $\alpha$, estrogen receptor-alpha; ER $\beta$, estrogen receptor-beta; FBS, fetal bovine serum; HS, horse serum; IL-6, interleukin-6; iNOS, inducible nitric oxide synthase; LDH, lactate dehydrogenase; LPS, lipopolysaccharide; MPP+, 1-methyl-4-phenyl-pyridine ion; MPTP, 1-methyl-4-phenyl-1,2,5,6-tetrahydropyridine; NGF, nerve growth factor; NO, nitric oxide; PD, Parkinson's disease; ROS, reactive oxygen species; RT, room temperature; RT-qPCR, Real time-quantitative polymerase chain reaction; SOD, superoxide dismutase; $\mathrm{TH}$, tyrosine hydroxylase; TNF $\beta$, tumor necrosis factor-beta
\end{abstract}

Key words: neuroprotection, oxidative stress, sesamin, lignans, $\mathrm{MPP}^{+}$, neurodegeneration, Parkinson's disease, neuroinflammation, dopamine, protein expression

Oxidative stress is regarded as a mediator of nerve cell death in several neurodegenerative disorders, such as Parkinson's disease. Sesamin, a lignan mainly found in sesame oil, is currently under study for its anti-oxidative and possible neuroprotective properties. We used 1-methyl-4-phenyl-pyridine $\left(\mathrm{MPP}^{+}\right)$ion, the active metabolite of the potent parkinsonism-causing toxin 1-methyl-4-phenyl-1,2,5,6-tetrahydropyridine, to produce oxidative stress and neurodegeneration in neuronal PC12 cells, which express dopamine, as well as neurofilaments. Our results show that picomolar doses of sesamin protected neuronal PC12 cells from $\mathrm{MPP}^{+}$-induced cellular death, as revealed by colorimetric measurements and production of reactive oxygen species. We also demonstrated that sesamin acted by rescuing tyrosine hydroxylase levels from $\mathrm{MPP}^{+}$-induced depletion. Sesamin, however, did not modulate dopamine transporter levels, and estrogen receptor-alpha and -beta protein expression. By examining several parameters of cell distress, we found that sesamin also elicited a strong increase in superoxide dismutase activity as well as protein expression and decreased catalase activity and the $\mathrm{MPP}^{+}$stimulated inducible nitric oxide synthase protein expression, in neuronal PC12 cells. Finally, sesamin possessed significant anti-inflammatory properties, as disclosed by its potential to reduce $\mathrm{MPP}^{+}$-induced interleukin- 6

${ }^{*}$ Correspondence to: Maria-Grazia Martinoli; Department of Biochemistry; Université du Québec à Trois-Rivières (UQTR); 3351, boul. des Forges, C.P. 500; Trois-Rivières, Québec G9A 5H7 Canada; Tel.: 819.376.501 1×3994; Fax: 819.376.5241; Email: martinol@uqtr.ca

Submitted: 08/21/08; Revised: 08/28/08; Accepted: 09/08/08

Previously published online as an Oxidative Medicine and Cellular Longevity E-publication: www.landesbioscience.com/journals/oximed/article/6958
mRNA levels in microglia. From these studies, we determined the importance of the lignan sesamin as a neuroprotective molecule and its possible role in complementary and/or preventive therapies of neurodegenerative diseases.

\section{Introduction}

A large body of experimental evidence supports a role for oxidative stress as mediator of nerve cell death in several neurodegenerative disorders, such as Parkinson disease (PD). The degeneration of dopaminergic (DAergic) neurons located in the substantia nigra characterizes PD and leads to a decline of dopamine (DA) as well as its biosynthetic enzyme, tyrosine hydroxylase $(\mathrm{TH})$, and its high-affinity cellular transporter (DAT). As reported recently, apoptotic death of DA neurons may be initiated by oxidative stress and neuroinflammation. ${ }^{1-3}$ Besides, elevated iron levels, decreased glutathione levels, impaired mitochondrial complex 1 activity and increased superoxide dismutase (SOD) activity have been observed in PD brains. ${ }^{4-6}$

1-Methyl-4-phenyl-1,2,5,6-tetrahydropyridine (MPTP) is a neurotoxin that causes Parkinson-like symptoms in humans, monkeys and mice. ${ }^{7-9}$ This toxin is largely employed as an experimental model to study therapeutic strategies against PD. 1-Methyl-4-phenylpyridine ion $\left(\mathrm{MPP}^{+}\right)$, the active metabolite of MPTP, is selectively taken up in DAergic neurons by DAT and actively transported into the mitochondria where it interferes with the respiratory chain and inhibits complex 1, inducing energy depletion and producing reactive oxygen species (ROS), such as superoxide anions. ${ }^{10,11}$ Superoxide anions can react with nitric oxide (NO) to produce the potent oxidant peroxynitrite, which has been implicated in the development of many neurological diseases. ${ }^{1,12,13}$ To date, however, the precise mechanism of $\mathrm{MPP}^{+}$-induced ROS generation is still under discussion. ${ }^{13}$ 


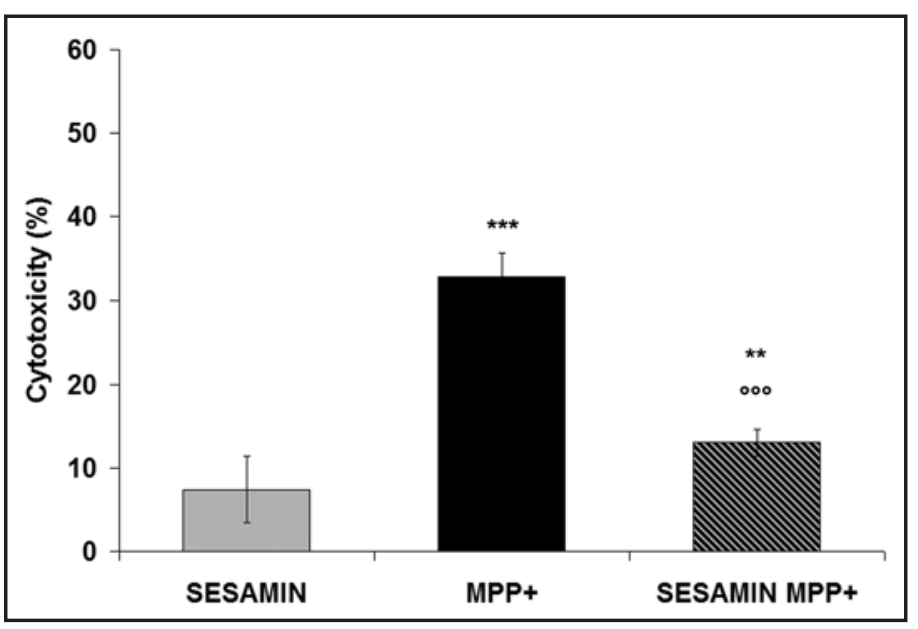

Figure 1. Effect of sesamin on MPP+-induced toxicity, as revealed by measuring LDH activity in supernatants after $24 \mathrm{~h}$ of treatment. Neuronal cells were pretreated with 10-12 M sesamin for $3 \mathrm{~h}$, and then MPP+ was added for 24 h. The control medium was subtracted from all absorbance measurements, as described in Materials and Methods. $\mathrm{n}=6 .{ }^{* *} \mathrm{p}<0.01$ and ${ }^{* *} \mathrm{p} p 0.001$ vs. sesamin alone; ${ }^{000} \mathrm{p}<0.001$ vs $\mathrm{MPP}^{+}$.

On the other side, sesamin, a phytonutrient of the class of lignans, is a lipophilic compound found in sesame seeds and sesame seed oil and is known for its antioxidant role. ${ }^{14-16}$ Sesamin as well as sesamol and sesaminol, the other 2 primary compounds in sesame, are likely responsible for the increased stability of sesame oil against autooxidation and the development of rancidity caused by free radicals. ${ }^{17}$ Indeed, sesamin is recognized to have several positive physiological effects, such as hypocholesterolemic, ${ }^{18}$ antihypertensive actions, ${ }^{19-21}$ and regulates lipid and alcohol metabolism in the liver. ${ }^{22}$ It is also known to protect against rotenone-induced loss of DA cells in mice ${ }^{23}$ and to inhibit lipopolysaccharide (LPS)-mediated activation of microglial cells in vitro. ${ }^{24}$

In this study, we investigated the neuroprotective, antioxidative and anti-inflammatory actions of sesamin in a model of DA neurons, neuronal PC12 cells. ${ }^{25,26} \mathrm{MPP}^{+}$was used to induce oxidative damage in these cells and stimulate pro-inflammatory cytokine production in the microglial cells line N9. ${ }^{27,28}$ Our results show that picomolar doses of sesamin protect neuronal PC12 cells from oxidative stress by reducing $\mathrm{MPP}^{+}$-evoked cellular death and by decreasing ROS production. Moreover, sesamin restores TH protein expression after $\mathrm{MPP}^{+}$-induced reduction without modulating DAT protein levels. Our data also reveal that sesamin increases SOD activity and SOD protein production as well as diminishes catalase (CAT) activity, indicating a rescue role for sesamin in the oxidative metabolism of DA neurons. Finally, our study demonstrates that sesamin decreases inducible NO synthase (iNOS) protein expression in neuronal cells and lowers mRNA levels of the potent pro-inflammatory cytokine interleukin-6 (IL-6) in microglial cells. In this comprehensive study, we outline the importance of the lignan sesamin as a neuroprotective molecule and its possible potential in complementary and/or preventive therapies of neurodegenerative diseases.

\section{Results}

Sesamin reduces $\mathrm{MPP}^{+}$-induced cytotoxicity and $\mathrm{MPP}^{+}$production of ROS. We measured the protective effect of pretreatment with

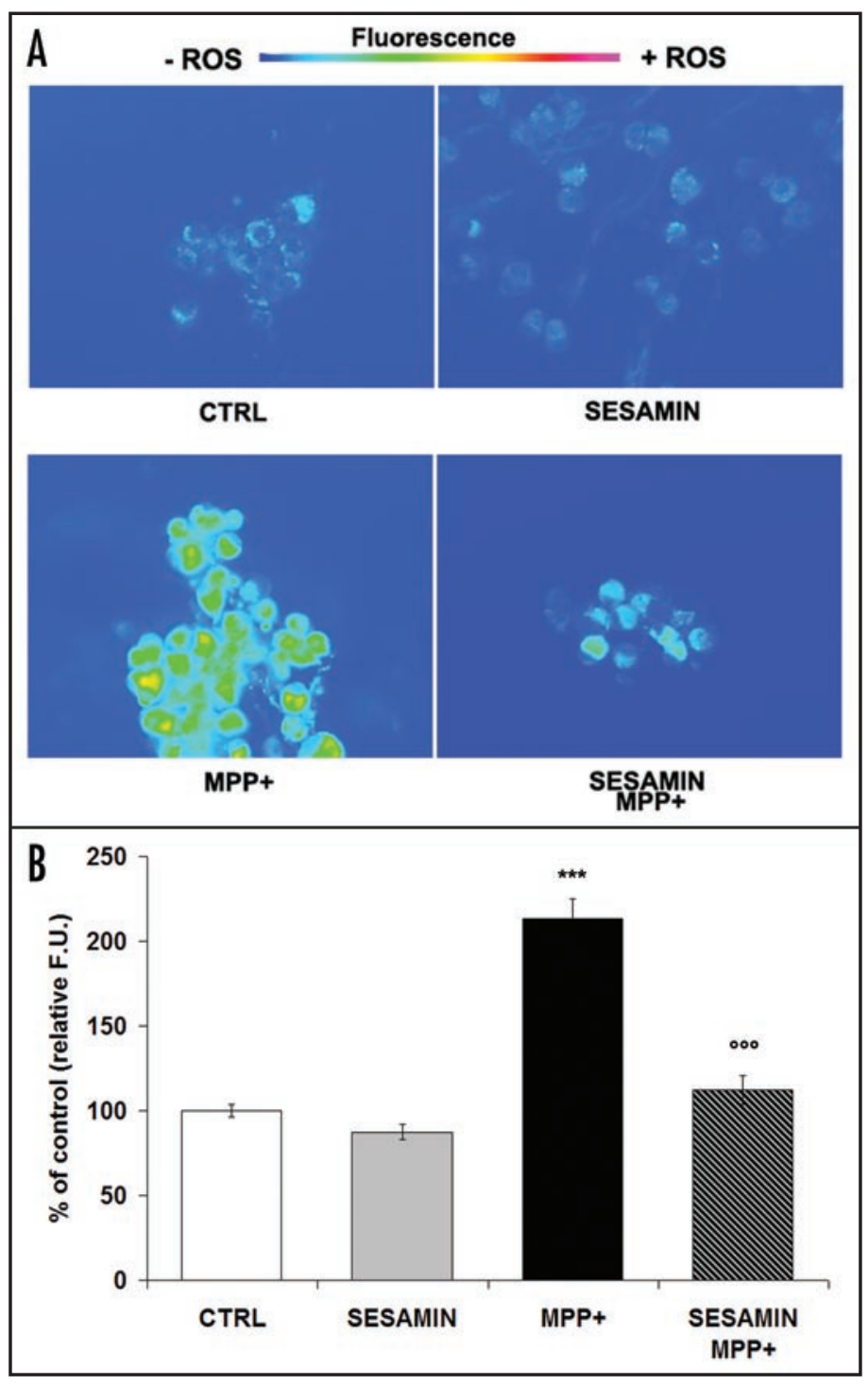

Figure 2. Rhodamine detection of ROS within neuronal PC12 cells. DHR is oxidized to fluorescent rhodamine in the presence of ROS. (A) Fluorescence microphotographs, Ctrl: cells were treated with vehicle. Sesamin: cells were treated with 10-12 M sesamin. MPP+: cells were treated with $5 \mathrm{mM}$. Sesamin + MPP+: cells were pretreated with sesamin for $3 \mathrm{~h}$ and then $\mathrm{MPP}^{+}$was administered. A marked signal is evident only in neuronal PC 12 cells treated with MPP+ but not in those treated with medium (CTRL) or sesamin alone. (B) Semi-quantitative image analysis. Fluorescent units (F.U.). Magnification $\times 400 . n=3 .{ }^{* *} p<0.001$ vs CTRL or sesamin alone; ${ }^{\circ 00} p$ $<0.001$ vs. MPP+

$1 \mathrm{pM}$ sesamin on $\mathrm{MPP}^{+}$-induced neuronal death. Figure 1 shows significant cell death after 24-h exposure to $\mathrm{MPP}^{+}$. Pretreatment with $10^{-12} \mathrm{M}$ sesamin prior to the production of oxidative stress greatly attenuated $\mathrm{MPP}^{+}$toxicity in neuronal PC12 cells. Specifically, sesamin protected neuronal $\mathrm{PC} 12$ cells against $\mathrm{MPP}^{+}$by reducing $\mathrm{MPP}^{+}$-evoked cellular death by $60 \%$. Figure 2 illustrates the rhodamine detection of ROS in neuronal PC12 cells. The nonflourescent dye DHR was converted to rhodamine in the presence of ROS. ${ }^{31,34,35}$ Figure 2A shows low levels of rhodamine fluorescence in control neuronal PC12 cells as well as in cells treated with sesamin alone, after $24 \mathrm{~h}$ (Fig. 2A, CTRL and sesamin, respectively), whereas 


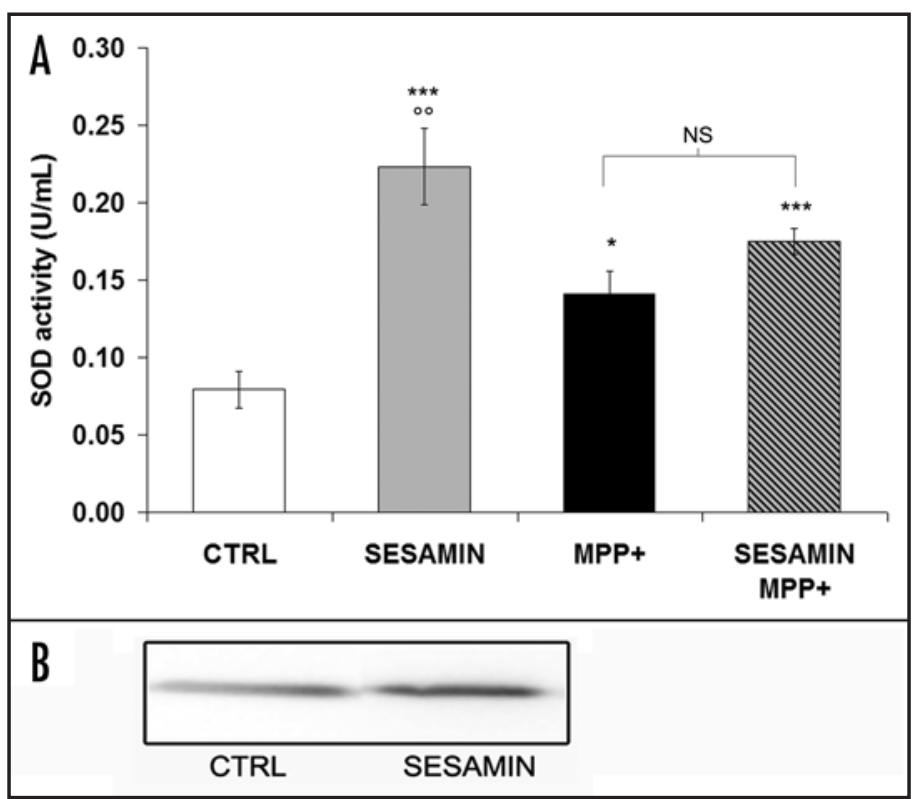

Figure 3. SOD activity (A) and SOD protein expression (B). (A) Sesamin markedly increased SOD activity in our experimental conditions. MPP+ also upregulated SOD activity by generating superoxide ions. SOD activity levels were increased over control values when sesamin was administered prior to $\mathrm{MPP}^{+}$. (B) Western blots indicate increased SOD protein expression when sesamin was added to the medium in neuronal PC12 cells. ${ }^{* * *} p<0.001$ and ${ }^{*} p<0.05$ vs CTRL; ${ }^{\circ} \mathrm{p}<0.01$ vs. $\mathrm{MPP}^{+} ; \mathrm{MPP}^{+}$vs. sesamin $+\mathrm{MPP}^{+}$is nonsignificative (NS)

a marked signal was detected in $\mathrm{MPP}^{+}$-treated neuronal cells (Fig. 2A, $\left.\mathrm{MPP}^{+}\right)$. On the other hand, cells treated with sesamin prior to $\mathrm{MPP}^{+}$ demonstrated a dampened signal in comparison to $\mathrm{MPP}^{+}$alone (Fig. $2 \mathrm{~A}$, sesamin $\left.+\mathrm{MPP}^{+}\right)$, suggesting a scavenging action of sesamin on $\mathrm{MPP}^{+}$-induced oxidative stress. Figure $2 \mathrm{~B}$ reports on the semiquantitative analysis of rhodamine fluorescence presented in figure $2 \mathrm{~A}$, revealing high-level fluorescence in the presence of $\mathrm{MPP}^{+}$and a very significant reduction $(\mathrm{p}<0.001)$ when the neuronal cells were pretreated with sesamin prior to $\mathrm{MPP}^{+}$.

Effect of sesamin on MPP ${ }^{+}$-induced increase in SOD and CAT activity. We used tetrazolium salt to detect superoxide radicals, as described in Materials and Methods. If SOD was present in the sample, the superoxide radicals would be dismutated by the enzyme. Figure 3 illustrates that sesamin alone increased SOD activity (Fig. $3 A)$. Interestingly, sesamin also heightened SOD protein expression (Fig. 3B) in the same experimental paradigm, as revealed by Western blot analysis, indicating a shielding role for sesamin in pretreatment experiments. Our results also show that $\mathrm{MPP}^{+}$increased both SOD and CAT activities, confirming a cellular response to $\mathrm{MPP}^{+}$production of ROS (Fig. 2), as demonstrated in vivo. ${ }^{36}$ When sesamin was administered prior to $\mathrm{MPP}^{+}$, we still detected an increment of SOD activity compared to the control condition (Fig. 3A). However, we did not observe any statistically-significant difference in SOD activity compared to $\mathrm{MPP}^{+}$levels. Figure $4 \mathrm{~A}$ reveals that sesamin alone decreased CAT activity and Fig 4B shows no apparent modulation of CAT protein expression. More importantly, sesamin reduced the $\mathrm{MPP}^{+}$-induced increase in CAT activity (Fig. 4A) when administered prior to $\mathrm{MPP}^{+}$, supporting an anti-oxidant role for sesamin in $\mathrm{MPP}^{+}$-treated cellular systems.

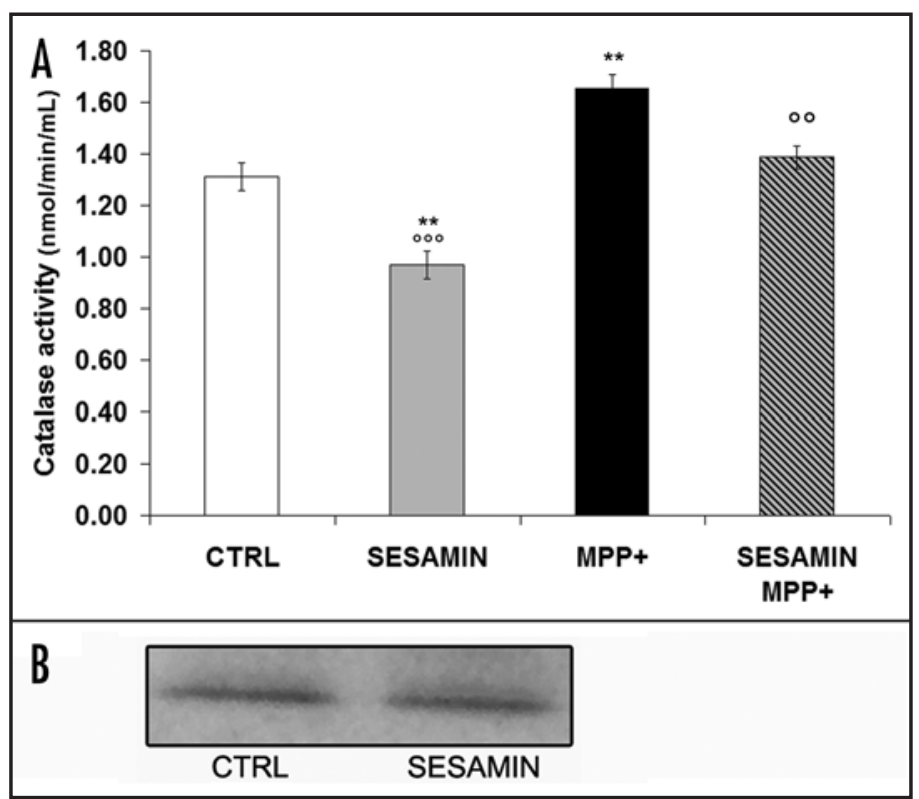

Figure 4. CAT activity (A) and CAT protein expression (B). (A) CAT activity was significantly reduced in the presence of sesamin whereas it was increased when $\mathrm{MPP}^{+}$was administered. Treatment of neuronal PC 12 cells with sesamin prior to $\mathrm{MPP}^{+}$reduced MPP+-induced CAT activity levels. (B) Western blots. ${ }^{* *} p<0.01$ and vs CTRL; ${ }^{\circ 0} p<0.01$ and ${ }^{\circ 00} p<0.001$ vs. MPP+

Sesamin rescues TH protein expression without modulating DAT protein level. $\mathrm{TH}$ is the rate-limiting enzyme for DA production. TH protein expression was decreased after treatment with $\mathrm{MPP}^{+}$, whereas sesamin alone did not modulate it (Fig. 5A). Interestingly, when the cells were co-treated with $\mathrm{MPP}^{+}$and sesamin, a slight but constant increase in TH protein expression was manifested, suggesting a neuroprotective role for sesamin in DA neurons. Figure 5B depicts that DAT protein levels were downregulated by $\mathrm{MPP}^{+}$, as already reported, ${ }^{25,26}$ and they were not impacted by sesamin alone. Pretreatment with sesamin before $\mathrm{MPP}^{+}$caused a slight decline in DAT protein levels which was not statistically significant in comparison to $\mathrm{MPP}^{+}$values.

Sesamin does not modulate ER $\alpha$ or ER $\beta$ protein expression. $\mathrm{MPP}^{+}$administration did not influence ER $\alpha$ or ER $\beta$ protein expression in neuronal PC12 cells, as already demonstrated. ${ }^{25,26}$ Sesamin, alone or in combination with $\mathrm{MPP}^{+}$, also did not alter ER $\alpha$ or ER $\beta$ protein expression (Fig. 6A and B, and Fig. 6C and D, respectively), indicating that the intracellular actions of sesamin do not involve the nuclear ERs. Interestingly, immunofluorescence also revealed the cytoplasmic and nuclear localization of $E R \alpha$, whereas ER $\beta$ appeared to be localized exclusively in the cytoplasm (Fig. 6B and $D$, respectively).

Sesamin modulates iNOS protein expression. Western blotting quantified the protein expression of iNOS, the enzyme mainly responsible for NO synthesis. Molecules that can inhibit iNOS may have anti-inflammatory activity. Figure 7 shows that when neuronal $\mathrm{PC} 12$ cells were exposed to $\mathrm{MPP}^{+}$, iNOS production was augmented as expected and already demonstrated. ${ }^{37}$ In Figure 7, we also report that sesamin alone reduced iNOS production and that its administration prior to $\mathrm{MPP}^{+}$provoked a marked decrease of $\mathrm{MPP}^{+}$-induced iNOS production, sustaining a scavenging role of sesamin against reactive nitrogen species. 


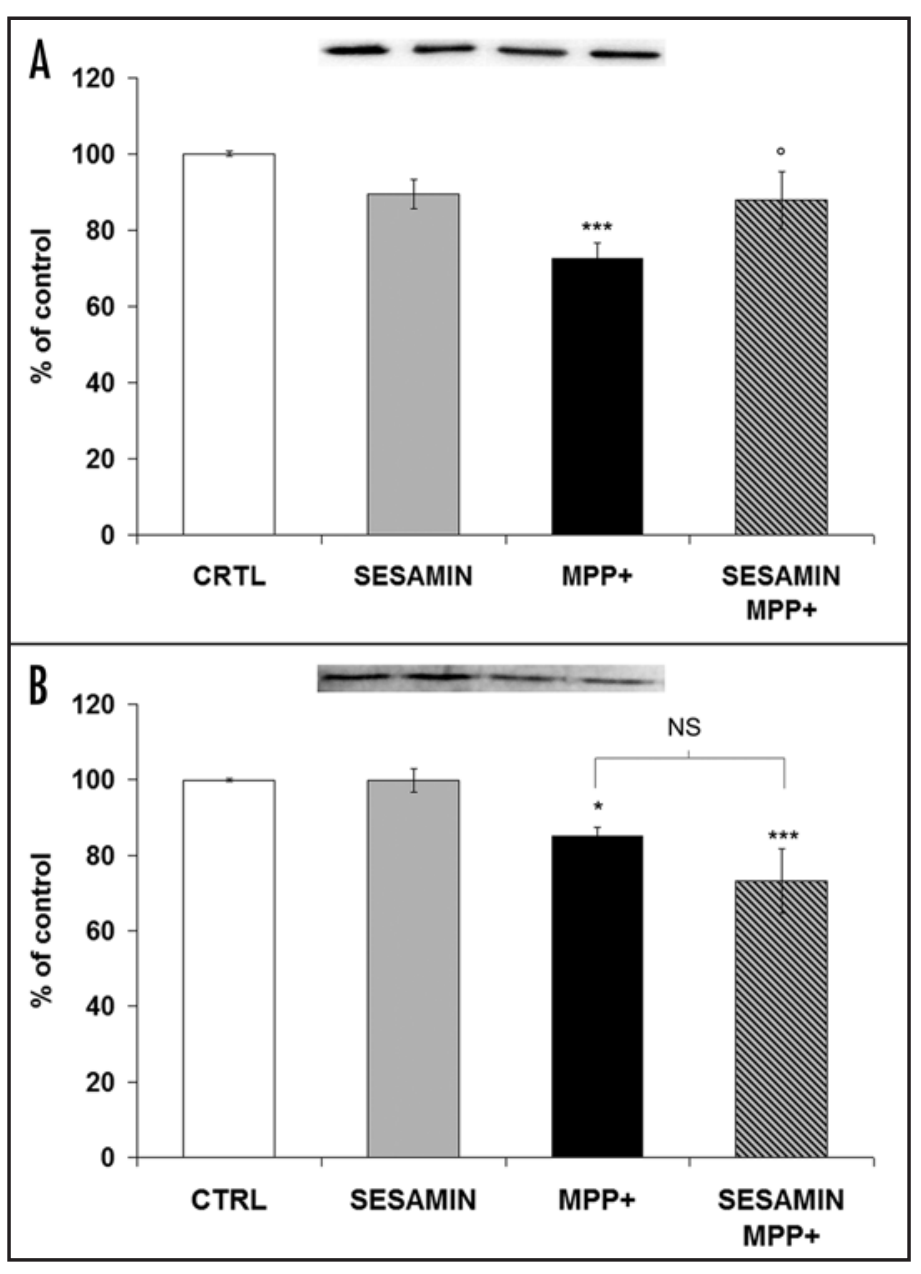

Figure 5. TH protein expression (A) and DAT protein expression (B). (A) Sesamin did not modulate TH expression when used alone in neuronal PC12 cells. When it was administered prior to MPP+, a slight but constant increase of $\mathrm{TH}$ protein expression was apparent. (B) Western blots revealed that sesamin did not modulate DAT protein levels. MPP+ decreased DAT levels. We could not detect any statistically-significant variation when the cells were pretreated with sesamin before MPP+ administration. ${ }^{* *} p<$ 0.001 and ${ }^{*} p<0.05$ vs CTRL; ${ }^{\circ} p<0.05$ vs. $\mathrm{MPP}^{+} ; \mathrm{MPP}^{+}$vs. sesamin + $\mathrm{MPP}^{+}$is nonsignificative (NS).

Sesamin diminishes $\mathrm{MPP}^{+}$-induced IL-6 mRNA in microglial cells. By RT-qPCR, we measured the expression of the potent pro-inflammatory cytokine IL-6. Figure 8 shows that $\mathrm{MPP}^{+}$induced the activation of N9 microglial cells by dramatically increasing IL-6 mRNA levels. When sesamin was administered alone, no IL-6 was detectable, whereas the pretreatment of neuronal PC12 cells with sesamin $3 \mathrm{~h}$ before $\mathrm{MPP}^{+}$elicited a reduced pattern of IL- 6 gene expression, suggesting sesamin's significant anti-inflammatory role.

\section{Discussion}

A growing body of literature is reporting a positive association between the consumption of foods and beverages containing high levels of natural antioxidants and the prevention of several agedependent diseases, such as cancer, stroke, osteoporosis and coronary heart disorders ${ }^{38}$ as well as Alzheimer's disease, ${ }^{39,40}$ opposite to the effects of high-calorie diets. ${ }^{41}$ In this study, we tested neuronal PC12 cells, a known, reliable and efficient paradigm for the investigation of oxidative stress and neuroprotection of DA neurons. ${ }^{25,42}$ After NGF administration, PC12 cells differentiate into the neuronal-like phenotype that secretes high DA levels and expresses TH, DAT, neurofilaments as well as ER $\alpha$ and ER $\beta .{ }^{25,43-46}$ It has already been demonstrated that various natural molecules exert anti-oxidative actions on mammalian cells, but these effects often require micromolar concentrations which would likely be impossible to sustain in vivo in humans due, in part, to the rapid metabolism of these phytonutrients. ${ }^{47-49}$ In this study, we examined the neuroprotective, antioxidant and anti-inflammatory consequences of low doses of sesamin $\left(10^{-12} \mathrm{M}\right)$, the major component of sesame oil. The positive outcomes we reported in neuronal culture, using picomolar doses of sesamin on parameters of neuroprotection, oxidative metabolism and neuroinflammation, are supported by the fact that sesamin is likely to accumulate in serum and in the brain, being less susceptible to conjugation in the liver. ${ }^{50}$ In particular, we demonstrated that picomolar doses of sesamin can protect DA neuronal cells from $\mathrm{MPP}^{+}$-induced cellular death by reducing intracellular ROS production. Indeed, non-fluorescent DHR has the capacity to enter cells and, once in, it is oxidized by oxygen species (superoxide anion, peroxynitrite) in fluorescent rhodamine. ${ }^{35}$ Accordingly, our results show increased rhodamine fluorescence after $\mathrm{MPP}^{+}$treatment and reduced fluorescence when sesamin is administered to neuronal $\mathrm{PC} 12$ cells prior to $\mathrm{MPP}^{+}$.

Currently, many clues point to the involvement of oxidative stress in the pathogenesis of PD (reviewed in refs. 51 and 52). On the one hand, it is now also recognized that estrogen replacement therapy in postmenopausal women reduces the risk of neurodegenerative diseases, particularly $\mathrm{PD}, 53$ possibly because the antioxidant properties of estrogens contribute to their neuroprotective actions. Nevertheless, clinical trials have raised growing concern about the secondary hormonal outcomes of hormone replacement therapy. ${ }^{54}$ Yet, phytoestrogens are naturally-occurring molecules that may exert neuroprotective effects similar to those of estrogens ${ }^{25,55,56}$ and have lesser hormonal actions. In our study, sesamin did not modulate ER $\alpha$ or ER $\beta$, making it unlikely that these nuclear receptors are involved in its neuroprotective outcomes.

MPTP has been widely used as a DA neurotoxin because it causes a severe Parkinson-like syndrome in humans, monkeys and mice. ${ }^{7-9}$ MPTP can produce oxidative stress in neurons by various mechanisms. ROS are generated during MPTP metabolism to MPDP and then to $\mathrm{MPP}^{+}$, by monoamino oxidase $\mathrm{B}$ in astrocytes. Moreover, massive DA release after $\mathrm{MPP}^{+} / \mathrm{MPTP}$ administration evokes excessive amounts of $\mathrm{H}_{2} \mathrm{O}_{2}$, resulting in oxidative stress. $\mathrm{MPP}^{+}$can also elicit ROS release through the inhibition of mitochondrial respiration by impairing $\mathrm{Na}^{+} / \mathrm{K}^{+}$-ATPase function and leading to neuronal depolarization. ${ }^{11,57}$ Then, the levels of TH protein, the DA key chain metabolic enzyme, are reduced in vivo after MPTP administration. ${ }^{58}$ Our present findings demonstrated prevention of the $\mathrm{MPP}^{+}$-induced decline in TH expression when sesamin was administered prior to $\mathrm{MPP}^{+}$, indicating a neuroprotective action of sesamin in DA neurons. Besides, we did not detect any modulation of DAT protein levels by sesamin, yet a specific effect of sesamin on TH expression was sustained. This is significant since DAT exerts its critical function by transporting DA into presynaptic cells; thus, molecules or pathologies that disrupt DAT could have a profound impact on the behaviors and physiological conditions it mediates. ${ }^{59,60}$ DAT is also 


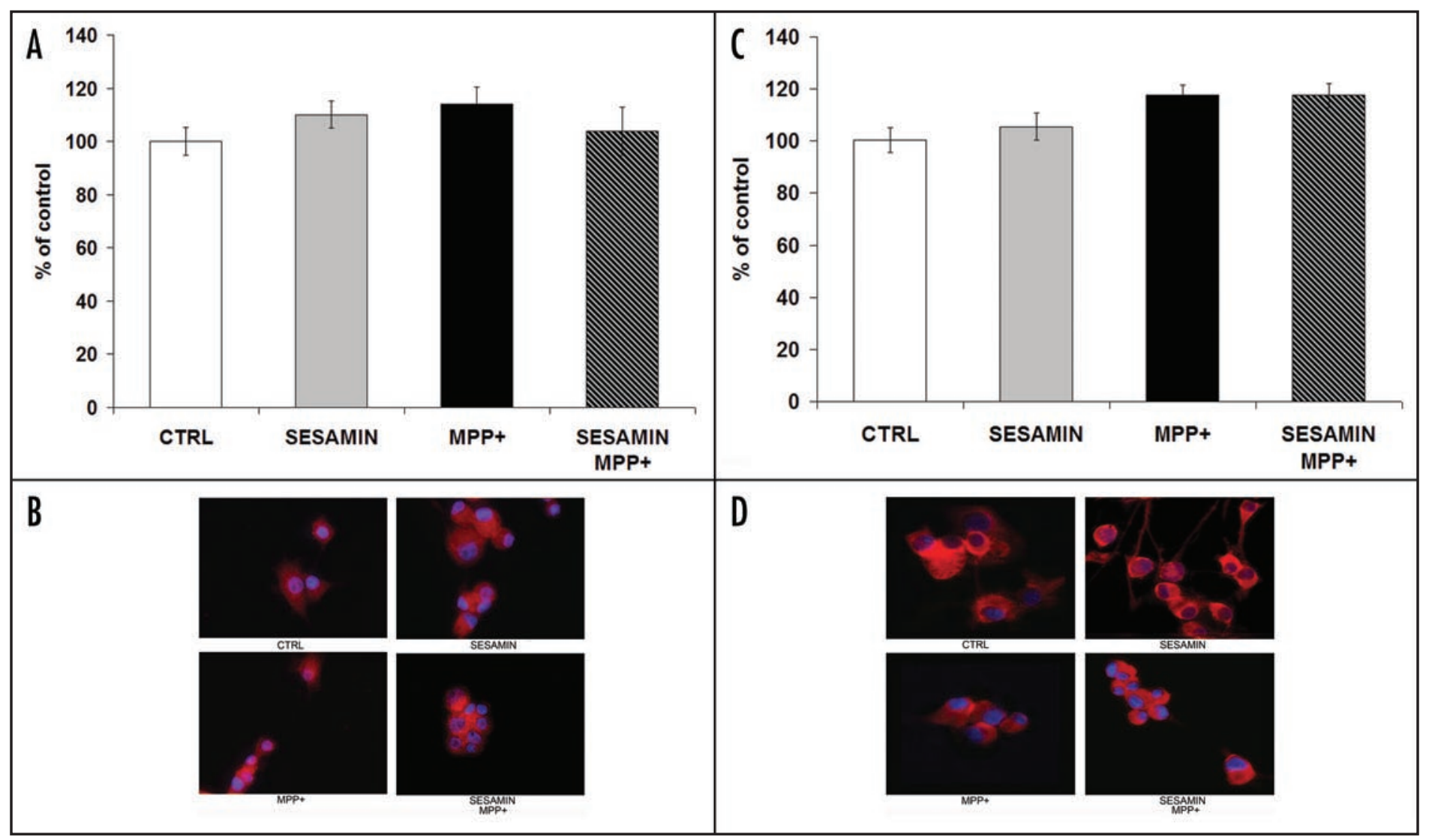

Figure 6. ER $\alpha$ (A and $B$ ) and ER $\beta$ (C and D) protein expression, as revealed by immunofluorescence in neuronal PC 12 cells. No statistically-significant difference of ER $\alpha$ or ER $\beta$ protein expression was observed after each treatment. Microfluorescence panels (A and C): ER $\alpha$ and ER $\beta$ proteins as revealed by monoclonal antibodies (red staining with Cy3); nuclei were coloured blue with DAPI, as described in Materials and methods. Histograms (B and D): semiquantitative analysis of the fluorescent signal shown above. CTRL, sesamin alone, MPP+, MPP+ + sesamin in both panels. Magnification $x 400$.

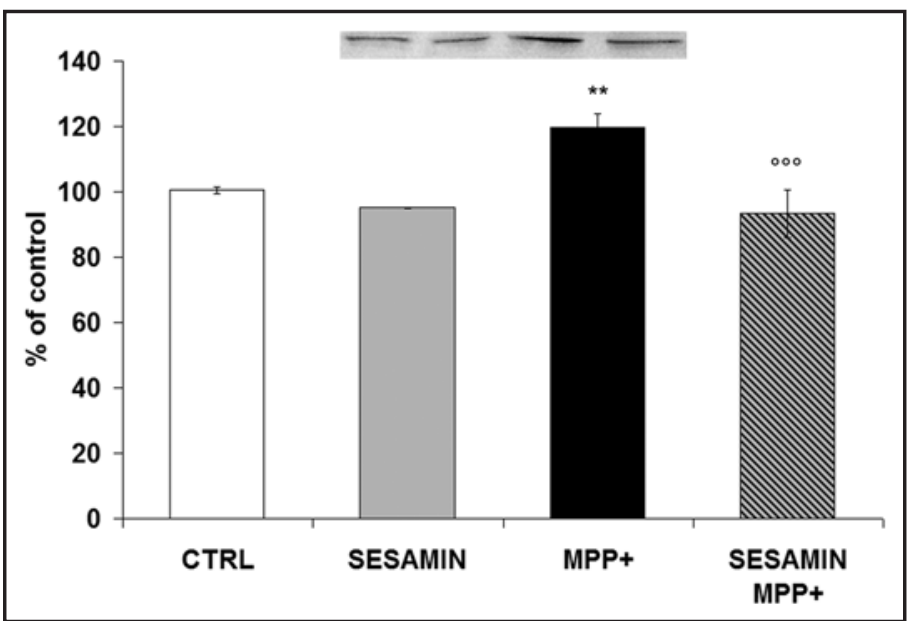

Figure 7. iNOS protein expression as revealed in neuronal PC12 cells after sesamin and MPP+ administration. 10-12 M sesamin slightly decreased iNOS protein expression and MPP ${ }^{+}$markedly increased iNOS protein levels in our cellular paradigm. When sesamin was administered prior to MPP+ a significant decline of iNOS was detected. ${ }^{*} p<0.01$ vs CTRL; ${ }^{\circ} p$ 0.001 v.s MPP+.

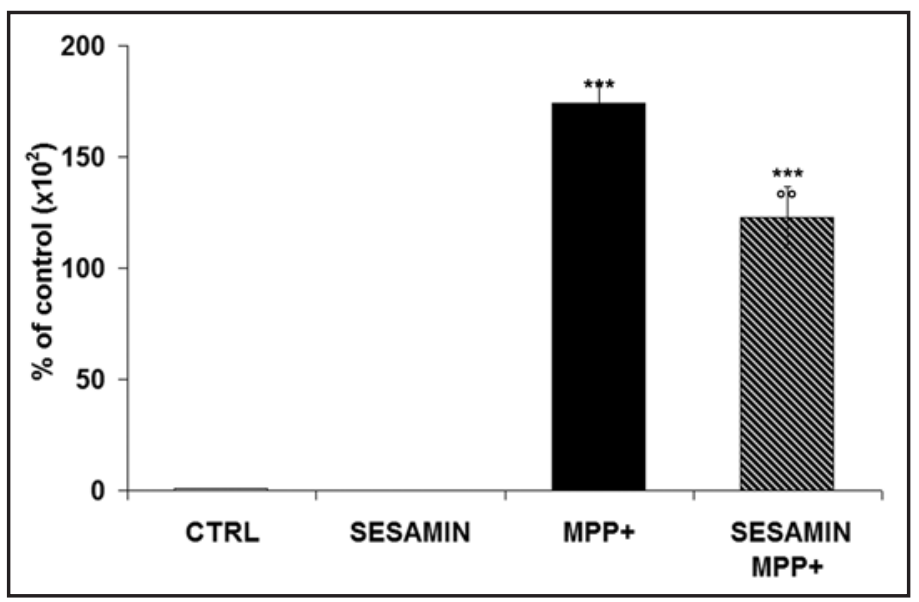

Figure 8. IL-6 mRNA levels shown by RT-qPCR. N9 microglia cells were first treated or not with sesamin for $3 \mathrm{~h}$, then $\mathrm{MPP}^{+}$was added or not. MPP+ clearly induced a significant increase of IL-6 mRNA levels, but when microglial cells were treated with sesamin prior to $\mathrm{MPP}^{+}$, we detected a significant decline of IL-6 mRNA. $n=3 .{ }^{* *} p<0.001$ vs CTRL, ${ }^{\circ} p<<0.01$ vs MPP+. 
known to be sensitive to inhibition by ROS and possibly by NOS. ${ }^{13}$ Our results showing reduced DAT protein levels after $\mathrm{MPP}^{+}$administration confirm previous data. ${ }^{26}$ However, in our experiments, we could not demonstrate the recovery of DAT protein expression when sesamin was given prior to $\mathrm{MPP}^{+}$, indicating no acting defense of sesamin against $\mathrm{MPP}^{+}$-induced damage. Alternatively, the picomolar doses of sesamin we tested were not sufficient to specifically modulate DAT expression against the relatively high doses of $\mathrm{MPP}^{+}$ we used. These relatively high doses of $\mathrm{MPP}^{+}$were required in our cellular paradigm as well as in others ${ }^{61,62}$ to reach significant cellular death over a short time period.

We also analyzed the effects of sesamin on parameters of cell distress as well as markers of neuroinflammation. Indeed, increased iron levels, decreased glutathione levels, impaired mitochondrial complex 1 activity and heightened SOD activity have been observed in PD brains. ${ }^{4-6}$ Moreover, the apoptotic death of DA neurons may be initiated by oxidative stress and neuroinflammation. ${ }^{2,3}$ In vivo studies suggest that sesamin protects the liver against Fe-induced oxidative damage by decreasing liver enzyme activities involved in lipogenesis and by increasing those implicated in fatty acid oxidation. ${ }^{63,64}$ Other recent data report that dietary sesame seed increase the levels of vitamin $\mathrm{C}$ and $\mathrm{E}$, two antioxidative vitamins, in various tissues. ${ }^{65}$

Augmented SOD activity demonstrates that sesame lignans may enhance the ability to eliminate superoxide radicals formed during $\mathrm{Fe}^{2+}$-induced oxidative stress. ${ }^{14}$ Accordingly, we found increased SOD activity as well as SOD protein expression when sesamin was administered alone in the medium, indicating a protective role in pretreatment experiments. In addition, several other natural and synthetic molecules are reported to heighten SOD activity in various cellular systems. ${ }^{66-68} \mathrm{MPP}^{+}$also augmented SOD activity in our experiments, as described in the recent literature where MPTP increased SOD activity by generating superoxide ions. ${ }^{36}$ In our experimental conditions, pretreatment with sesamin prior to $\mathrm{MPP}^{+}$ administration elevated SOD activity in comparison to control cells, but this was similar to SOD activity after $\mathrm{MPP}^{+}$treatment. The apparent contrasting action of SOD should be analyzed by comparing it with the results obtained by fluorescent rhodamine. Indeed, low ROS levels, illustrated by low rhodamine fluorescence (sesamin alone and sesamin $+\mathrm{MPP}^{+}$), sustained the ability of sesamin to induce SOD activity and protein expression, as demonstrated by our data. When $\mathrm{MPP}^{+}$was administered, rhodamine fluorescence indicated high ROS levels and, consequently, the cells responded by augmenting SOD activity, as already reported. ${ }^{36}$ Our findings clearly show that SOD activity may be induced by 2 different mechanisms, a protective mechanism and a response-to-stress mechanism. Pretreatment with sesamin prior to $\mathrm{MPP}^{+}$administration indicates low ROS levels, as revealed by rhodamine fluorescence, and suggests that the SOD activity induced by sesamin pretreatment may scavenge $\mathrm{MPP}^{+}$-generated ROS. However, other data are needed to determine the balance between sesamin- and $\mathrm{MPP}^{+}$-induced SOD activity.

CAT activity is another parameter of oxidative stress. Our results showed that sesamin decreased CAT activity and sesamin pretreatment reduced the $\mathrm{MPP}^{+}$-induced increase in CAT activity, confirming a scavenging role for sesamin in the pretreatment experimental condition.

To date, ROS can no longer be regarded as the sole damaging species in MPTP/MPP+-induced toxicity. ${ }^{13,69}$ Certainly, NO is an apoptosis-inducer, and iNOS is a key enzyme in charge of producing large NO quantities. Sesamin and sesamin metabolites are known to induce endothelial NOS and thus playing an important anthypertensive function. ${ }^{19,21}$ In this study, we demonstrated that sesamin markedly reduced the $\mathrm{MPP}^{+}$-induced upregulation of iNOS expression, corroborating other data on similar effects of curcumin in PC12 cells. ${ }^{70}$

Finally, microglia activation and neuroinflammation have been proposed as candidates that mediate the apoptotic cell death of DA neurons. Currently, various phytonutrients, such as resveratrol, quercetin, silymarin, epigallocatechin-3-gallate and sesamin, have been found to dampen microglial activation in vitro and in vivo. ${ }^{71-74}$ Others report that sesamin inhibits LPS-mediated activation of microglial cells in vitro ${ }^{24,75}$ as well as iNOS mRNA levels. ${ }^{76}$ MPTP has recently been reported to activate microglia in vivo, ${ }^{27,77}$ and to induce TNF $\alpha$ expression. ${ }^{78}$ Pro-inflammatory cytokines, identified in the post-mortem substantia nigra, striatum, and cerebrospinal fluid of PD patients, include TNF $\alpha$, IL-1 $\beta,-2$ and -6 and interferon-gamma. ${ }^{79,80}$ We studied the N9 microglial cell line to quantitatively analyze mRNA levels of the potent pro-inflammatory cytokine IL-6. Our results are the first to quantitatively indicate that sesamin can indeed reduce mRNA IL-6, when the inflammation process is induced by $\mathrm{MPP}^{+}$, supporting a complex role of sesamin in the mechanisms of neuroprotection, both at the neuronal and glial levels.

In conclusion, our comprehensive findings point to a distinct role of the sesame lignan sesamin as a potent neuroprotective antioxidant and anti-inflammatory agent. Certainly, cellular studies on natural compounds that could restore damaged mitochondrial functions and interfere with the production of ROS and NOS could benefit complementary alternative medicine and preventive therapies of neurodegenerative diseases.

\section{Materials and Methods}

Materials. All reagents were purchased from Sigma (St. Louis, MO) unless noted otherwise.

Cell culture and treatments. PC12 cells (ATCC, Rockville, $\mathrm{MD}$ ) were maintained in a controlled environment at $37^{\circ} \mathrm{C}$ and in $5 \% \mathrm{CO}_{2}$ atmosphere. They were grown in RPMI-1640 medium, without phenol red, supplemented with $5 \%$ fetal bovine serum (FBS), 10\% horse serum (HS, Invitrogen, Toronto, ON, Canada) and gentamicin $(50 \mu \mathrm{g} / \mathrm{ml})$. The culture medium was changed every 3 days. For each experiment, cellular density was 30,000 cells $/ \mathrm{cm}^{2}$. Neuronal differentiation was induced for 8 days by $50 \mathrm{ng} / \mathrm{ml}$ nerve growh factor (NGF) in RPMI-1640 medium supplemented with $1 \%$ FBS, as already described. ${ }^{25}$ To examine the effect of sesamin on $\mathrm{MPP}^{+}$-evoked oxidative stress, the cells were pretreated with sesamin (1 pM) for $3 \mathrm{~h}$ and then exposed to $\mathrm{MPP}^{+}(5 \mathrm{mM})$ for $24 \mathrm{~h}^{25}$ This concentration of sesamin was chosen as the lowest dose able to rescue cells from $\mathrm{MPP}^{+}$-induced cellular death, after kinetic and dose-response studies (data not shown). The microglial cell line N9 (a generous gift from Dr. L. Vallières, Centre de recherche, CHUL, Quebec, QC, Canada) was grown in 10\% HS in Dulbecco's modified Eagle's medium-F12-ham (DMEM-F12). To assess the influence of sesamin on $\mathrm{MPP}^{+}$-induced N9 inflammation, the cells were pretreated with sesamin for $3 \mathrm{~h}$ and then exposed to $\mathrm{MPP}^{+}(500 \mu \mathrm{M})$ for $24 \mathrm{~h}$. All experiments were performed in phenol red-free medium 
and charcoal-stripped serum to remove steroids from the medium.

Cytotoxicity measurements. Cytotoxicity was evaluated by colorimetric assay (Roche Diagnostics, Laval, QC, Canada) based on the measurement of lactate dehydrogenase (LDH) activity released from damaged cells into the supernatant, as already described in reference $25 . \mathrm{LDH}$ is a stable cytoplasmic enzyme present in all cells. It is rapidly released into the cell culture supernatant upon damage of the plasma membrane. The amount of enzyme activity detected in the culture supernatant correlates with the portion of lysed cells. ${ }^{29,30}$ Briefly, $100 \mu \mathrm{l}$ of cell-free supernatant were taken to quantify LDH activity by measuring absorbance at a wavelength of $490 \mathrm{~nm}$ on a microplate reader (Thermolab System, Franklin, MA). Total cellular LDH was determined by lysing the cells with $1 \%$ Triton X-100 (high control); the assay medium served as a low control and was subtracted from all absorbance measurements:

Cytotoxicity $(\%)=($ Experimental value - Low control $) \times 100 \%$

(High control - Low control)

Dihydrorhodamine 123 (DHR) detection. The scavenging effect of sesamin against $\mathrm{MPP}^{+}$-induced oxidative stress was evaluated by DHR assay, as described previously. ${ }^{31,32}$ In brief, a stock solution of DHR (Molecular Probes, Eugene, OR) was prepared in dimethylsulfoxide (DMSO) to a concentration of $10 \mathrm{mM}$, deoxygenated with nitrogen and stored at $-80^{\circ} \mathrm{C}$. Neuronal PC12 cells were treated with DMSO (Ctrl), sesamin and/or $\mathrm{MPP}^{+}$. Then, they were quickly washed with PBS $0.1 \mathrm{M}$ and exposed to $250 \mu \mathrm{l}$ of DHR at $37^{\circ} \mathrm{C}$ for $20 \mathrm{~min}$. The slides were immediately examined under an Orthoplan fluorescence microscope (Leica, Wetzlar, Germany), photographed with a Qimaging camera (Nikon, Mississauga, ON, Canada) and analyzed by NIS-Element 2.2 software (Nikon).

Detection of SOD and CAT activity. Neuronal cells were mechanically harvested and then collected by centrifugation at $2,000 \mathrm{~g}$ for $10 \mathrm{~min}$ at $4^{\circ} \mathrm{C}$. The pellets were homogenized in $1 \mathrm{ml}$ of cold $20 \mathrm{mM}$ HEPES buffer, pH 7.2 (1 mM EGTA, $210 \mathrm{mM}$ mannitol and $70 \mathrm{mM}$ sucrose) and sonicated (3 times, $5 \mathrm{~s}$ ). The samples were then centrifuged at $1,500 \mathrm{~g}$ for $5 \mathrm{~min}$ at $4^{\circ} \mathrm{C}$, and the supernatant was assayed according to the manufacturer's protocol (Superoxide Dismutase Assay Kit or Catalase Assay Kit, Cayman Chemical, Ann Arbor, MI). One unit of SOD activity is defined as the amount of enzyme needed to exhibit 50\% dismutation of superoxide radicals. The reaction was monitored at $450 \mathrm{~nm}$ with a microplate reader (Thermolab System).

Electrophoresis and immunoblot analysis. NGF-differentiated PC12 cells were grown and treated in collagen-coated 6-well plates. Total cellular proteins were extracted with Nuclear Extraction Kit (Active Motif, Carlsbad, CA), diluted in $50 \mu \mathrm{l}$ of lysis solution, and their concentration determined with a BCA Protein Assay Kit (Pierce, Rockford, IL). Equal amounts of protein $(1 \mu \mathrm{g})$ were loaded onto $10 \%$ polyacrylamide gel-sodium dodecyl sulfate. After electrophoretic separation (180 volts, $45 \mathrm{~min}$ ), the polyacrylamide gels were transferred onto nylon PVDF membranes $(0.22-\mu \mathrm{m}$ pore size, BioRad, Hercules, CA) at $60 \mathrm{~V}$ for $2 \mathrm{~h}$. The membranes were blocked with $5 \%$ non-fat powder milk for $1 \mathrm{~h}$ at room temperature (RT). Immunoblotting was performed overnight at $4^{\circ} \mathrm{C}$ with anti-TH antibody (1:2,000) (Sigma), anti-DAT antibody (1:50)
(Santa Cruz Biotechnology, Santa Cruz, CA), anti-Cu/Zn SOD antibody (1:1000) (StressMarq,Victoria, BC, Canada), anti-CAT antibody (1: 50) (Santa Cruz Biotechnology), and anti-iNOS antibody (1:50) (StressGene, Biotech, Ann Arbor, MI). The following day, the membranes were washed, and anti-mouse POD-conjugated secondary antibody diluted 1:10,000 was added for $1 \mathrm{~h}$ at RT. Immunopositive signals were visualized by enhanced chemiluminescence with the AlphaEase FC imaging system (Alpha Innotech, San Leandro, CA) and analyzed with AlphaEase FC software (Alpha Innotech).

Immunofluorescence. Neuronal PC12 cells were plated on collagen-coated coverslips in 24-well plates and neuronal differentiation was induced for 8 days with NGF, as described above. After treatment, the cells were fixed in $4 \%$ paraformaldehyde for $1 \mathrm{~h}$ at $4^{\circ} \mathrm{C}$, then permeabilized with fish skin gelatin buffer + Triton (TBS, $1 \%$ BSA, $0.18 \%$ fish skin gelatin, $0.1 \%$ Triton-X, $0.02 \%$ sodium azide) for $30 \mathrm{~min}$ at RT. The fixed cells were incubated with monoclonal anti-estrogen receptor-alpha (ER $\alpha)$ antibody (StressGene) diluted $1: 500$, for $2 \mathrm{~h}$ at RT or with polyclonal anti-ER $\beta$ antibody (Santa Cruz Biotechnology) diluted 1:50, for $2 \mathrm{~h}$ at RT. Then, the slides were washed with $\mathrm{PBS}$ and stained with Cy3-conjugated secondary antibody (Medicorp, Montreal, QC, Canada) diluted 1:500, for $2 \mathrm{~h}$ at RT. Finally, 4',6-diamidino-2-phenylindole (DAPI, $5 \mu \mathrm{g} / \mathrm{ml}$ ) was added for $10 \mathrm{~min}$ at $37^{\circ} \mathrm{C}$ to counterstain all nuclei. Coverslips were mounted with a Molecular Probes Prolong Antifade Kit (Invitrogen). Images were acquired with an Orthoplan fluorescence microscope (Leica) with a high-pressure mercury burner and necessary filter cubes, then analyzed with NIS-Element 2.2 software (Nikon).

Real time-quantitative polymerase chain reaction (RT-qPCR). Total RNA was extracted with Sigma's GenElute Mammalian Total RNA extraction kit. RNA was spectrophotometrically measured for each condition, and $1 \mu \mathrm{g}$ of total RNA was reverse-transcribed with $25 \mathrm{U}$ of M-MULV reverse transcriptase, $1.5 \mu \mathrm{M} \mathrm{dNTP}$, and $10 \mu \mathrm{M}$ of random hexamers. RT-qPCR was then performed in a MiniOpticon Real-time PCR system (BioRad) in $20 \mu l$-sized reactions containing $4 \mu \mathrm{l}$ of the cDNA mixture, $0.3 \mu \mathrm{M}$ of each forward and reverse primer and $10 \mu \mathrm{l}$ of iQ SYBR Green Supermix (BioRad). Incubation at $95^{\circ} \mathrm{C}$ for $3 \mathrm{~min}$ was followed by 40 cycles of $15 \mathrm{~s}$ at $95^{\circ} \mathrm{C}$ and $30 \mathrm{~s}$ at $61^{\circ} \mathrm{C}$. Primers for tumor necrosis factor-beta (TNF $\beta$ ) (5'-CAC GAG GTC CAG CTC TTT TC-3' and 5'-AGT GCA AAG GCT CCA AAG AA-3'), IL-6 (5'-TTC CAT CCA GTT GCC TTC TT-3' and 5'-ATT TCC ACG ATT TCC CAG AG-3'), Ubiquitin C (5'-AGC CCA GTG TTA CCA CCA AG-3' and 5'-TCA CAC CCA AGA ACA AGC AC-3'), -microglobulin (5'-ATG GGA AGC CGA ACA TAC TG-3' and (5'-CAG TCT CAG TGG GGG TGA AT-3') were synthesized at Sigma Genosys (Oakville, ON, Canada). Reactions were performed in duplicate, and 3 independent preparations of cDNA were studied. A 10-fold dilution series was obtained from a random pool of cDNA ranging from $x 10$ to $\times 100,000$ dilution. Mean cycle threshold values $(\mathrm{Ct})$ for each dilution were plotted against $\log 10$ of cDNA input to generate efficiency plots. The reaction efficiency for each gene assay was calculated according to the following equation:

$$
\mathrm{E}=10(-1 / \text { slope })
$$


where E was the reaction efficiency, and 'slope' was the slope of the line generated in efficiency plots. All PCR efficiencies were above 90\%. In all PCR experiments, post-PCR DNA-melting curve analysis was undertaken to assess amplification specificity. DNA-melting was carried out at a temperature ramping rate of $1^{\circ} \mathrm{C}$ per step with 1 -s rest at each step. Relative gene transcription was calculated by the comparative $\mathrm{Ct}$ method, using the real-time efficiency values of each gene. cDNA levels among the samples were normalized by the expression level of 2 internal control genes: ubiquitin and $\beta$-microglobulin. These housekeeping genes were chosen with the GeNORM algorithm. ${ }^{33}$ A normalization factor was calculated with the geometric mean of the 2 reference genes. The normalized expression of each gene of interest was calculated by dividing the raw quantities for each sample by the appropriate normalization factor. ${ }^{33}$

Statistical analysis. Significant differences between treatment effects were determined by 1 -way ANOVA, followed by Tukey's posthoc test and Student-Newman-Keuls analysis with the GraphPad Instat program, version 3.06, for Windows ${ }^{\circledR}$ (San Diego, CA, www. graphpad.com). Data are expressed as the means \pm S.E.M. from 3-15 independent experiments. Asterisks $\left({ }^{*}\right)$ indicate statistical differences between the treatment and respective control conditions, and circles (o) show statistical differences between the treatment and $\mathrm{MPP}^{+}$ conditions.

\section{Acknowledgements}

This work was funded by a Natural Sciences and Engineering Research Council (Canada) grant to M.G.M. and Fonds de Recherche en Santé du Québec (Québec) studentships to V.L.C. and J.B.

\section{References}

1. Zhang Y, Dawson VL, Dawson TM. Oxidative stress and genetics in the pathogenesis of Parkinson's disease. Neurobiol Dis 2000; 7:240-50.

2. Jenner P. Oxidative stress in Parkinson's disease. Ann Neurol 2003; 53 Suppl 3:S26-36; discussion S-8.

3. Marchetti B, Abbracchio MP. To be or not to be (inflamed) - Is that the question in antiinflammatory drug therapy of neurodegenerative disorders? Trends Pharmacol Sci 2005; 26:517-25.

4. Andersen JK. Oxidative stress in neurodegeneration: cause or consequence? Nat Med 2004; 10 Suppl:S18-25.

5. Alam ZI, Jenner A, Daniel SE, Lees AJ, Cairns N, Marsden CD, Jenner P, Halliwell B. Oxidative DNA damage in the parkinsonian brain: an apparent selective increase in 8-hydroxyguanine levels in substantia nigra. J Neurochem 1997; 69:1196-203.

6. Maier CM, Chan PH. Role of superoxide dismutases in oxidative damage and neurodegenerative disorders. Neuroscientist 2002; 8:323-34.

7. Langston JW, Irwin I. MPTP: current concepts and controversies. Clin Neuropharmacol 1986; 9:485-507.

8. Heikkila RE, Sieber BA, Manzino L, Sonsalla PK. Some features of the nigrostriatal dopaminergic neurotoxin 1-methyl-4-phenyl-1,2,3,6-tetrahydropyridine (MPTP) in the mouse. Mol Chem Neuropathol 1989; 10:171-83.

9. Kopin IJ, Markey SP. MPTP toxicity: implications for research in Parkinson's disease. Annu Rev Neurosci 1988; 11:81-96.

10. Schober A. Classic toxin-induced animal models of Parkinson's disease: 6-OHDA and MPTP. Cell Tissue Res 2004; 318:215-24.

11. Segura Aguilar J, Kostrzewa RM. Neurotoxins and neurotoxic species implicated in neurodegeneration. Neurotoxicity Res 2004; 6:615-30.

12. Koppenol WH, Moreno JJ, Pryor WA, Ischiropoulos H, Beckman JS. Peroxynitrite, a cloaked oxidant formed by nitric oxide and superoxide. Chem Res Toxicol 1992; 5:83442 .

13. Obata T. Nitric oxide and $\mathrm{MPP}^{+}$-induced hydroxyl radical generation. J Neural Transm 2006; 113:1131-44.

14. Hemalatha S, Raghunath M, Ghafoorunissa. Dietary sesame oils inhibits iron-induced oxidative stress in rats [corrected]. Br J Nutr 2004; 92:581-7.

15. Suja KP, Jayalekshmy A, Arumughan C. Free radical scavenging behavior of antioxidant compounds of sesame (sesamum indicum L.) in DPPH $\left({ }^{*}\right)$ system. J Agric Food Chem 2004; 52:912-5.

16. Ghafoorunissa, Hemalatha S, Rao MV. Sesame lignans enhance antioxidant activity of vitamin E in lipid peroxidation systems. Mol Cell Biochem 2004; 262:195-202.
17. Shahidi F, Wanasundara PK. Phenolic antioxidants. Crit Rev Food Sci Nutr 1992; 32:67103.

18. Hirata F, Fujita K, Ishikura Y, Hosoda K, Ishikawa T, Nakamura H. Hypocholesterolemic effect of sesame lignan in humans. Atherosclerosis 1996; 122:135-36.

19. Lee CC, Chen PR, Lin S, Tsai SC, Wang BW, Chen WW, Tsai CE, Shyu KG. Sesamin induces nitric oxide and decreases endothelin-1 production in HUVECs: possible implications for its antihypertensive effect. J Hypertens 2004; 22:2329-38.

20. Noguchi T, Ikeda K, Sasaki Y, Yamamoto J, Seki J, Yamagata K, Nara Y, Hara H, Kakuta H, Yamori Y. Effects of vitamin E and sesamin on hypertension and cerebral thrombogenesis in stroke-prone spontaneously hypertensive rats. Hypertens Res 2001; 24:735-42.

21. Nakano D, Kwak CJ, Fujii K, Ikemura K, Satake A, Ohkita M, Takaoka M, Ono Y, Nakai M, Tomimori N, Kiso Y, Matsumura Y. Sesamin metabolites induce an endothelial nitric oxide-dependent vasorelaxation through their antioxidative property-independent mechanisms: possible involvement of the metabolites in the antihypertensive effect of sesamin. J Pharmacol Exp Ther 2006; 318:328-35.

22. Kiso Y. Antioxidative roles of sesamin, a functional lignan in sesame seed, and it's effect on lipid- and alcohol-metabolism in the liver: a DNA microarray study. BioFactors (Oxford, England) 2004; 21:191-6.

23. Fujikawa T, Kanada N, Shimada A, Ogata M, Suzuki I, Hayashi I, Nakashima K. Effect of sesamin in Acanthopanax senticosus HARMS on behavioral dysfunction in rotenoneinduced parkinsonian rats. Biol Pharm Bull 2005; 28:169-72.

24. Jeng KC, Hou RC, Wang JC, Ping LI. Sesamin inhibits lipopolysaccharide-induced cytokine production by suppression of $\mathrm{p} 38$ mitogen-activated protein kinase and nuclear factor-kappaB. Immunol Lett 2005; 97:101-6.

25. Gelinas S, Martinoli MG. Neuroprotective effect of estradiol and phytoestrogens on $\mathrm{MPP}^{+}$ induced cytotoxicity in neuronal PC12 cells. J Neurosci Res 2002; 70:90-6.

26. Gagne B, Gelinas S, Bureau G, Lagace B, Ramassamy C, Chiasson K, Valastro B, Martinoli MG. Effects of estradiol, phytoestrogens, and Ginkgo biloba extracts against 1-methyl-4phenyl-pyridine-induced oxidative stress. Endocrine 2003; 21:89-95.

27. Miwa H, Kubo T, Morita S, Nakanishi I, Kondo T. Oxidative stress and microglial activation in substantia nigra following striatal $\mathrm{MPP}^{+}$. Neuroreport 2004; 15:1039-44.

28. Henze C, Hartmann A, Lescot T, Hirsch EC, Michel PP. Proliferation of microglial cells induced by 1-methyl-4-phenylpyridinium in mesencephalic cultures results from an astrocyte-dependent mechanism: role of granulocyte macrophage colony-stimulating factor. J Neurochem 2005; 95:1069-77.

29. Martin A, Clynes M. Acid phosphatase: endpoint for in vitro toxicity tests. In Vitro Cell Dev Biol 1991; 27A:183-4.

30. Decker T, Lohmann-Matthes ML. A quick and simple method for the quantitation of lactate dehydrogenase release in measurements of cellular cytotoxicity and tumor necrosis factor (TNF) activity. J Immunol Meth 1988; 115:61-9.

31. Gelinas S, Bureau G, Valastro B, Massicotte G, Cicchetti F, Chiasson K, Gagne B, Blanchet J, Martinoli MG. Alpha and beta estradiol protect neuronal but not native PC12 cells from paraquat-induced oxidative stress. Neurotox Res 2004; 6:141-8.

32. Frantseva MV, Carlen PL, Perez Velazquez JL. Dynamics of intracellular calcium and free radical production during ischemia in pyramidal neurons. Free Radic Biol Med 2001; 31:1216-27.

33. Vandesompele J, De Preter K, Pattyn F, Poppe B, Van Roy N, De Paepe A, Speleman F Accurate normalization of real-time quantitative RT-PCR data by geometric averaging of multiple internal control genes. Genome Biol 2002; 3:RESEARCH0034.

34. Henderson LM, Chappell JB. Dihydrorhodamine 123: a fluorescent probe for superoxide generation? Eur J Biochem 1993; 217:973-80.

35. Kooy NW, Royall JA, Ischiropoulos H, Beckman JS. Peroxynitrite-mediated oxidation of dihydrorhodamine 123. Free Radic Biol Med 1994; 16:149-56.

36. Thomas B, Saravanan KS, Mohanakumar KP. In vitro and in vivo evidences that antioxidant action contributes to the neuroprotective effects of the neuronal nitric oxide synthase and monoamine oxidase-B inhibitor, 7-nitroindazole. Neurochem Int 2008; 52:990-1001.

37. Cheng $\mathrm{YH}$, Ding ST, Chang MH. Effect of fumonisins on macrophage immune functions and gene expression of cytokines in broilers. Arch Anim Nutr 2006; 60:267-76.

38. Galati G, Sabzevari O, Wilson JX, O'Brien PJ. Prooxidant activity and cellular effects of the phenoxyl radicals of dietary flavonoids and other polyphenolics. Toxicology 2002; 177:91104.

39. Anekonda TS. Resveratrol—A boon for treating Alzheimer's disease? Brain Res Rev 2006; 52:316-26.

40. Hartman RE, Shah A, Fagan AM, Schwetye KE, Parsadanian M, Schulman RN, Finn MB, Holtzman DM. Pomegranate juice decreases amyloid load and improves behavior in a mouse model of Alzheimer's disease. Neurobiol Dis 2006; 24:506-15.

41. Baur JA, Pearson KJ, Price NL, Jamieson HA, Lerin C, Kalra A, Prabhu VV, Allard JS, Lopez-Lluch G, Lewis K, Pistell PJ, Poosala S, Becker KG, Boss O, Gwinn D, Wang M, Ramaswamy S, Fishbein KW, Spencer RG, Lakatta EG, Le Couteur D, Shaw RJ, Navas P, Puigserver P, Ingram DK, de Cabo R, Sinclair DA. Resveratrol improves health and survival of mice on a high-calorie diet. Nature 2006; 444:337-42.

42. Chiasson K, Daoust B, Levesque D, Martinoli MG. Dopamine D2 agonists, bromocriptine and quinpirole, increase $\mathrm{MPP}^{+}$-induced toxicity in PC12 cells. Neurotox Res 2006 10:31-42.

43. Kadota T, Yamaai T, Saito Y, Akita Y, Kawashima S, Moroi K, Inagaki N, Kadota K. Expression of dopamine transporter at the tips of growing neurites of PC12 cells. J Histochem Cytochem 1996; 44:989-96. 
44. Nilsen J, Mor G, Naftolin F. Raloxifene induces neurite outgrowth in estrogen receptor positive PC12 cells. Menopause 1998; 5:211-6.

45. Chiasson K, Lahaie-Collins V, Bournival J, Delapierre B, Gelinas S, Martinoli MG. Oxidative stress and 17-alpha- and 17-beta-estradiol modulate neurofilaments differently. J Mol Neurosci 2006; 30:297-310.

46. Lee V, Trojanowski JQ, Schlaepfer WW. Induction of neurofilament triplet proteins in PC12 cells by nerve growth factor. Brain Res 1982; 238:169-80.

47. Vitaglione P, Sforza S, Galaverna G, Ghidini C, Caporaso N, Vescovi PP, Fogliano V, Marchelli R. Bioavailability of trans-resveratrol from red wine in humans. Mol Nutrition Food Res 2005; 49:495-504

48. Ross JA, Kasum CM. Dietary flavonoids: bioavailability, metabolic effects, and safety. Annual Rev Nutrition 2002; 22:19-34.

49. Umeda-Sawada R, Ogawa M, Igarashi O. The metabolism and distribution of sesame lignans (sesamin and episesamin) in rats. Lipids 1999; 34:633-7.

50. McCarty MF. Down-regulation of microglial activation may represent a practical strategy for combating neurodegenerative disorders. Medical hypotheses 2006; 67:251-69.

51. Drechsel DA, Patel M. Role of reactive oxygen species in the neurotoxicity of environmental agents implicated in Parkinson's disease. Free Radic Biol Med 2008; 44:1873-86.

52. Nunomura A, Moreira PI, Lee HG, Zhu X, Castellani RJ, Smith MA, Perry G. Neuronal death and survival under oxidative stress in Alzheimer and Parkinson diseases. CNS Neurol Disord Drug Targets 2007; 6:411-23.

53. Currie LJ, Harrison MB, Trugman JM, Bennett JP, Wooten GF. Postmenopausal estrogen use affects risk for Parkinson disease. Arch Neurol 2004; 61:886-8.

54. Rossouw JE, Anderson GL, Prentice RL, LaCroix AZ, Kooperberg C, Stefanick ML, Jackson RD, Beresford SA, Howard BV, Johnson KC, Kotchen JM, Ockene J. Risks and benefits of estrogen plus progestin in healthy postmenopausal women: principal results From the Women's Health Initiative randomized controlled trial. JAMA 2002; 288:321-33.

55. Esposito E, Rotilio D, Di Matteo V, Di Giulio C, Cacchio M, Algeri S. A review of specific dietary antioxidants and the effects on biochemical mechanisms related to neurodegenerative processes. Neurobiol Aging 2002; 23:719-35.

56. Di Matteo V, Esposito E. Biochemical and therapeutic effects of antioxidants in the treatment of Alzheimer's disease, Parkinson's disease, and amyotrophic lateral sclerosis. Curr Drug Targets 2003; 2:95-107.

57. Mytilineou. Mechanism of MPTP neurotoxicity. Mechanisms of Degeneration and Protection of the Dopaminergic System. Johnson City, TN: FP Graham Publ, 2001.

58. Blanchet J, Longpre F, Bureau G, Morissette M, Dipaolo T, Bronchti G, Martinoli MG. Resveratrol, a red wine polyphenol, protects dopaminergic neurons in MPTP-treated mice. Prog Neuropsychopharmacol Biol Psychiatry 2008; 32:1243-50.

59. Mehler-Wex C, Riederer P, Gerlach M. Dopaminergic dysbalance in distinct basal ganglia neurocircuits: implications for the pathophysiology of Parkinson's disease, schizophrenia and attention deficit hyperactivity disorder. Neurotox Res 2006; 10:167-79.

60. Salahpour A, Ramsey AJ, Medvedev IO, Kile B, Sotnikova TD, Holmstrand E, Ghisi V, Nicholls PJ, Wong L, Murphy K, Sesack SR, Wightman RM, Gainetdinov RR, Caron MG. Increased amphetamine-induced hyperactivity and reward in mice overexpressing the dopamine transporter. Proc Nat Acad Sci USA 2008; 105:4405-10.

61. Itano Y, Kitamura Y, Nomura Y. 1-Methyl-4-phenylpyridinium $\left(\mathrm{MPP}^{+}\right)$-induced cell death in PC12 cells: inhibitory effects of several drugs. Neurochem Int 1994; 25:419-24.

62. Fall CP, Bennett JP, Jr. Characterization and time course of $\mathrm{MPP}^{+}$-induced apoptosis in human SH-SY5Y neuroblastoma cells. J Neurosci Res 1999; 55:620-8.

63. Sirato-Yasumoto S, Katsuta M, Okuyama Y, Takahashi Y, Ide T. Effect of sesame seeds rich in sesamin and sesamolin on fatty acid oxidation in rat liver. J Agric Food Chem 2001; 49:2647-51.

64. Kushiro M, Takahashi Y, Ide T. Species differences in the physiological activity of dietary lignan (sesamin and episesamin) in affecting hepatic fatty acid metabolism. Br J Nutr 2004; 91:377-86.

65. Ikeda S, Abe C, Uchida T, Ichikawa T, Horio F, Yamashita K. Dietary sesame seed and its lignan increase both ascorbic acid concentration in some tissues and urinary excretion by stimulating biosynthesis in rats. J Nutr Sci Vitaminol 2007; 53:383-92.

66. An LJ, Guan S, Shi GF, Bao YM, Duan YL, Jiang B. Protocatechuic acid from Alpinia oxyphylla against $\mathrm{MPP}^{+}$-induced neurotoxicity in PC12 cells. Food Chem Toxicol 2006; 44:436-43.

67. Hou RC, Wu CC, Yang CH, Jeng KC. Protective effects of sesamin and sesamolin on murine BV-2 microglia cell line under hypoxia. Neurosci Lett 2004; 367:10-3.

68. Jung TW, Lee JY, Shim WS, Kang ES, Kim SK, Ahn CW, Lee HC, Cha BS. Rosiglitazone protects human neuroblastoma SH-SY5Y cells against acetaldehyde-induced cytotoxicity. Biochem Biophys Res Commun 2006; 340:221-7.

69. Gonzalez-Polo RA, Soler G, Rodriguezmartin A, Moran JM, Fuentes JM. Protection against $\mathrm{MPP}^{+}$neurotoxicity in cerebellar granule cells by antioxidants. Cell biol Int 2004; 28:37380 .

70. Chen J, Tang XQ, Zhi JL, Cui Y, Yu HM, Tang EH, Sun SN, Feng JQ, Chen PX. Curcumin protects PC12 cells against 1-methyl-4-phenylpyridinium ion-induced apoptosis by bcl-2mitochondria-ROS-iNOS pathway. Apoptosis 2006; 11:943-53.

71. Bureau G, Longpre F, Martinoli MG. Resveratrol and quercetin, two natural polyphenols, reduce apoptotic neuronal cell death induced by neuroinflammation. J Neurosci Res 2008; 86:403-10.

72. Bi XL, Yang JY, Dong YX, Wang JM, Cui YH, Ikeshima T, Zhao YQ, Wu CF. Resveratrol inhibits nitric oxide and TNF-alpha production by lipopolysaccharide-activated microglia. Int Immunopharmacol 2005; 5:185-93.
73. Li R, Huang YG, Fang D, Le WD. (-)-Epigallocatechin gallate inhibits lipopolysaccharideinduced microglial activation and protects against inflammation-mediated dopaminergic neuronal injury. J Neurosci Res 2004; 78:723-31.

74. Wang MJ, Lin WW, Chen HL, Chang YH, Ou HC, Kuo JS, Hong JS, Jeng KC. Silymarin protects dopaminergic neurons against lipopolysaccharide-induced neurotoxicity by inhibiting microglia activation. Eur J Neurosci 2002; 16:2103-12.

75. Hou RC, Huang HM, Tzen JT, Jeng KC. Protective effects of sesamin and sesamolin on hypoxic neuronal and PC12 cells. J Neurosci Res 2003; 74:123-33.

76. Hou RC, Chen HL, Tzen JT, Jeng KC. Effect of sesame antioxidants on LPS-induced NO production by BV2 microglial cells. Neuroreport 2003; 14:1815-9.

77. Gao JP, Sun S, Li WW, Chen YP, Cai DF. Triptolide protects against 1-methyl-4-phenyl pyridinium-induced dopaminergic neurotoxicity in rats: implication for immunosuppressive therapy in Parkinson's disease. Neurosci Bull 2008; 24:133-42.

78. Gomez-Santos C, Francisco R, Gimenez-Xavier P, Ambrosio S. Dopamine induces TNFalpha and TNF-R1 expression in SH-SY5Y human neuroblastoma cells. Neuroreport 2007; 18:1725-8.

79. Hunot S, Dugas N, Faucheux B, Hartmann A, Tardieu M, Debre P, Agid Y, Dugas B, Hirsch EC. FcepsilonRII/CD23 is expressed in Parkinson's disease and induces, in vitro, production of nitric oxide and tumor necrosis factor-alpha in glial cells. J Neurosci 1999; 19:3440-7.

80. Mogi M, Harada M, Narabayashi H, Inagaki H, Minami M, Nagatsu T. Interleukin (IL)-1 beta, IL-2, IL-4, IL-6 and transforming growth factor-alpha levels are elevated in ventricular cerebrospinal fluid in juvenile parkinsonism and Parkinson's disease. Neurosci Lett 1996; 211:13-6. 


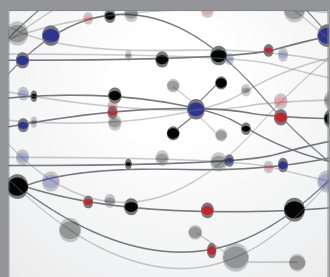

The Scientific World Journal
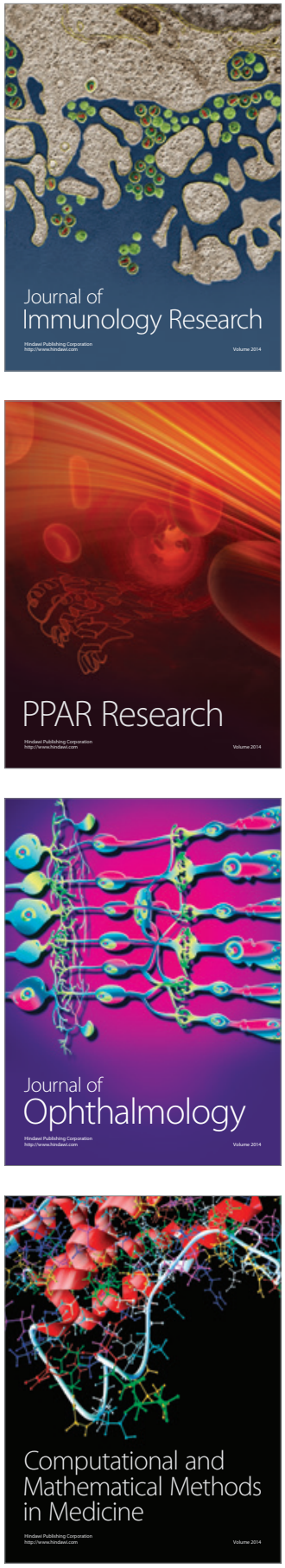

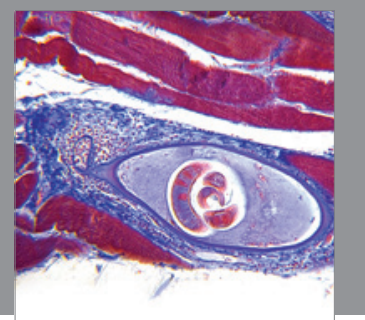

Gastroenterology

Research and Practice
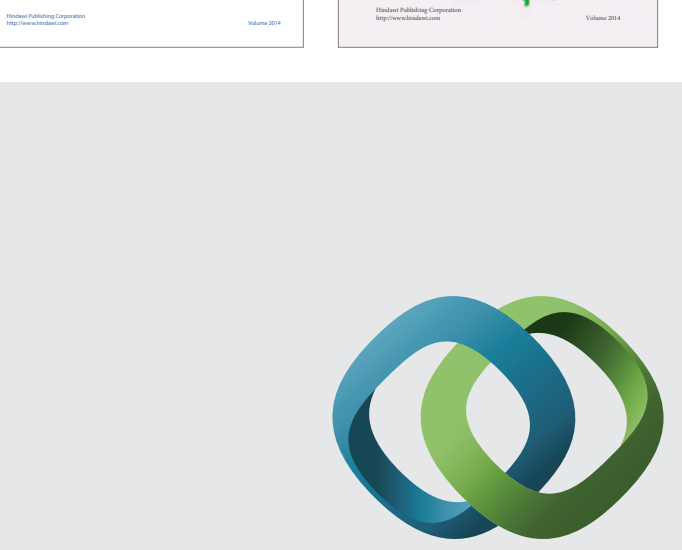

\section{Hindawi}

Submit your manuscripts at

http://www.hindawi.com
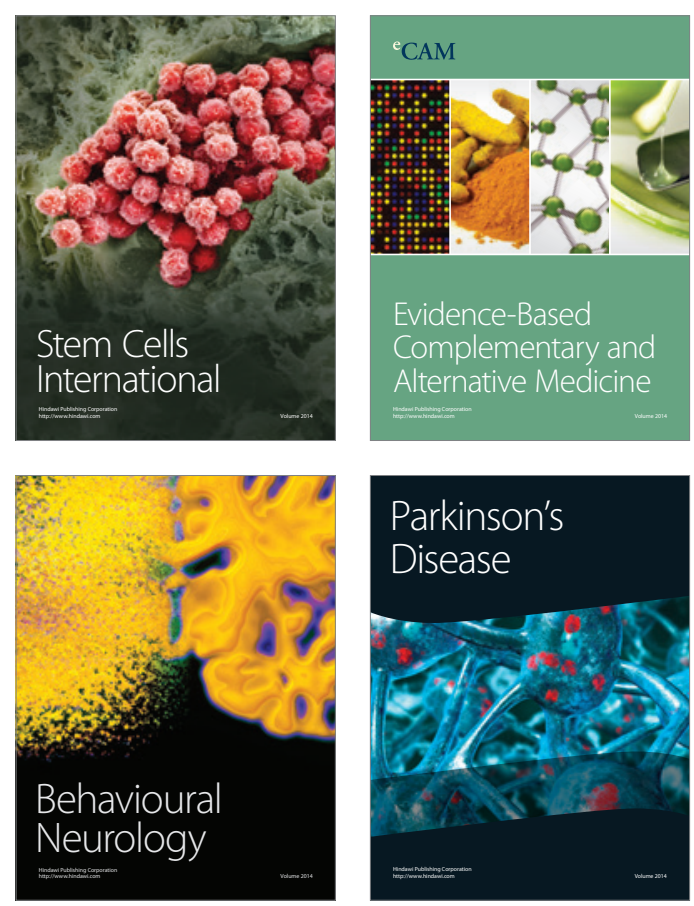

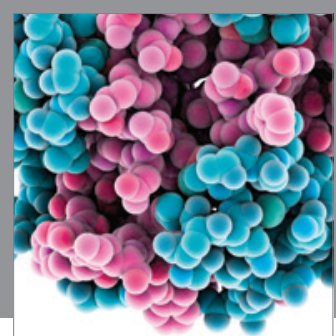

Journal of
Diabetes Research

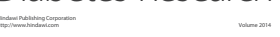

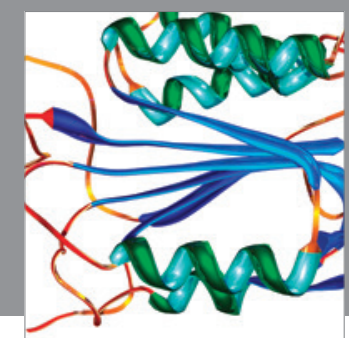

Disease Markers
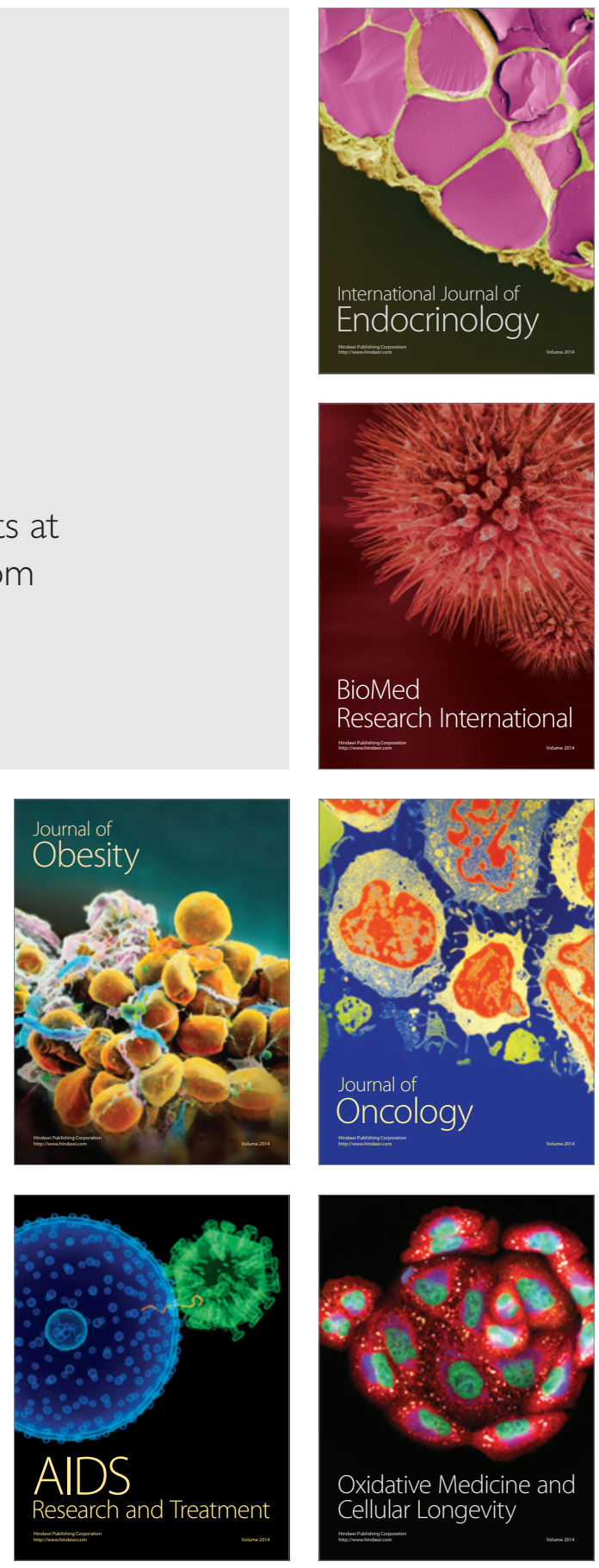